\title{
High spatial variability of coral, sponges and gorgonian assemblages in a well preserved reef
}

\author{
Patricia González-Díaz*, Gaspar González-Sansón, Sergio Álvarez Fernández \\ \& Orlando Perera Pérez \\ Center of Marine Research, University of La Habana, 16 No 114, Miramar, CP 11300, Ciudad Habana. Cuba; \\ patricia@cim.uh.cu, gasparg2001@yahoo.es, orlando@cim.uh.cu \\ * Corresponding author
}

Received 27-IV-2009. Corrected 20-IX-2009. Accepted 23-X-2009.

\begin{abstract}
The main goal of this research was to obtain baseline field data of the composition of sponges, corals, and gorgonian assemblages that can be used as a reference for future analyses of anthropogenic impact. We tested the hypothesis that relatively homogeneous and well preserved reef units can present notable natural variability in the composition of their communities which are unassociated with changes in land proximity or a human impact gradient. Research was carried out in July 2006 at Los Colorados reef, located in the northwestern region of Pinar del Río Province, Cuba at 12 sampling stations. The biotopes selected were crest, terrace edge and spur and grove. Ecological indicators were diversity of corals, species composition, density of corals, hydrocorals, gorgonians and sponges, and density of selected coral species. A total of 2659 colonies of scleractineans corals representing 36 species were counted. The most abundant species in the crest biotope were Millepora alcicornis, Acropora palmata and Porites astreoides; in the terrace edge and spur and grove, the most abundant species were Siderastrea siderea, Stephanocoenia intersepta, Porites astreoides, Agaricia agaricites and Montastraea cavernosa. We found differences among sites for several indicators (e.g. density of corals, sponges and gorgonians and for selected species), but they could not be associated to any gradient of land influence or human impact. Therefore, sites inside a relatively homogeneous reef unit can present notable natural differences in the composition of their communities. Rev. Biol. Trop. 58 (2): 621-634. Epub 2010 June 02.
\end{abstract}

Key words: natural variability, ecological indicators, benthic invertebrate's communities, biotopes, Cuba.

A general consensus exists of the serious decline of coral reefs worldwide (Hughes et al. 2003, Bellwood et al. 2004). This includes coral reefs in the Caribbean region and southern Florida (Wilkinson 2002). The degradation of these ecosystems is primarily due to over-harvesting, pollution, disease and climate change (Pandolfi 2003, Hughes et al. 2003, Bellwood et al. 2004). In many locations around the world, stresses caused by human activities on coral reefs exceeded their regenerative capacity causing dramatic shifts in coral species composition, abundance and diversity (Karlson \& Cornell 1998, Bellwood et al. 2004), as well as in other characteristics of coral assemblages, e.g. change in population structure of corals species, prevalence of disease and substrate cover (Bak \& Meesters 1998, Dale \& Beyeler 2001).

In the present context, knowledge about the status of coral reefs acquires more relevance in "pristine" sites. This is because these areas are essential as replicated control or reference areas (English et al. 1997, Underwood \& Chapman 2003). On the other hand, knowledge of pristine reefs is equally important for building an ecological baseline for future comparative research of the function and structure of degraded coral reefs. There is a general consensus regarding the use of baselines as an initial 
phase of research (English et al. 1997, Rogers et al. 2001, Hill \& Wilkinson 2004, Bellwood et al. 2004). To complete this knowledge, it is necessary to carry out research mainly on reef key functional groups (corals and reef fishes).

The complexity of marine systems, their inherent high variability, and the influence of multiple environmental factors or stressors, suggest that no single measure is adequate for assessing the effects of multiple stressors on biota and for establishing the mechanistic bases of these effects (Munkittrick \& McCarty 1995, Adams 2005). This philosophy has encouraged a holistic approach and integrative measurements. Following this line of thought, ecological indicators can be used to assess the condition of the environment, to provide an early warning signal of changes in the environment, or to diagnose the cause of an environmental problem. Ecological indicators need to capture the complexities of the ecosystems and should meet the following criteria: easily measurable, sensitive to stresses on the system, integrative, and with a known response to disturbances, among others (Dale \& Beyeler, 2001). Variation in abundance, community composition, diversity and richness of structural species like corals are critical to the dynamics of the whole community and they should be analyzed at different scales (Connell et al. 1997, Karlson \& Cornell 1998, Bellwood et al. 2004, Fabricius et al. 2004, Hughes et al. 2007).

Los Colorados in western Cuba is a well preserved reef area due to its distance from land and the very low population density in this region of the country (Oficina Nacional de Estadísticas 2005). Currently, the major environmental concern here is the proposed initiation of oil exploration (by mid 2009) in high seas areas close to these coral communities (AFP 2009). There is a potential risk for these reefs in the event that accidental discharges and spills occur.

This is the first detailed study that focuses on sessile invertebrate community structure and its natural spatial variation in Los Colorados reef. The main goal of the study is to obtain baseline field data for sponge, coral, and gorgonian assemblages that can be used as a reference for future analyses of the impact of human actions on this reef and on the entire northwestern region of Cuba (e.g. oil spills, other pollution events, tourism development). This research also provides inputs for a more comprehensive understanding of the status of these communities in the Gulf of Mexico basin.

We hypothesize that different sites inside a well preserved reef unit can present notable natural variability in the composition of the community. We propose that this natural variability will be detected in different magnitudes using different ecological indicators.

\section{MATERIALS AND METHODS}

Study area: Research was carried out in July 2006 in Los Colorados fringing reef (LC), located along the northwestern region of Pinar del Río Province, Cuba. This reef is part of an extended coral formation growing at the edge of a wide portion of the Cuban shelf, at approximately $40 \mathrm{~km}$ from the coast. The main shallow-water habitats in this region are fringing coral reefs, seagrass beds and nearshore muddy environments associated with mangrove prop-roots. This fringing reef has three main biotopes:

- Crest: dominated by Acropora palmata (with large sizes) and Millepora complanata. Mean depth is $1-3 \mathrm{~m}$ and the area is characterized by high wave energy and sunlight exposure. The substratum is mainly a rocky plain with sand patches.

- Terrace edge: a rocky plain dominated by corals and gorgonians with high species diversity. Substrate is covered mainly by algae. Slope is approximately $45^{\circ}$ and depth is between $15-19 \mathrm{~m}$. Wave and light exposure are attenuated by depth.

- Spur and groove: dominated by corals, gorgonians and sponges. Average dimensions for spurs are $15 \mathrm{~m}$ length, $1,5 \mathrm{~m}$ width and $1 \mathrm{~m}$ high. The substrate cover is formed by algae and sand. Substratum 
topography is mainly plain and the mean depth is $20-24 \mathrm{~m}$. Wave and light exposure are attenuated by depth.

These reefs are very far from any urban center $(40 \mathrm{kms})$ or land-based pollution source. There is no evidence of any kind of contamination (González et al. 2009). Small commercial vessels fish in these reefs targeting large-sized species (e.g., larger snappers, groupers, jacks) which are heavily overexploited (González et al. 2009).

Sampling procedure: Sampling was done at four sites located near existing marine light platforms along the shelf edge (Fig. 1). At each site a profile was defined perpendicular to the shelf edge and sampling stations were located in the biotopes described above. In total, 12 sampling stations (combination of sites and biotopes) were visited.

Species composition and the number of coral colonies were estimated in replicated sampling units (SU) at each station. In crest stations SU were measured in transect of $10 \mathrm{~m}$ in length $\mathrm{x} 1 \mathrm{~m}$ in wide (as suggested by Hill \& Wilkinson 2004) and ten replicates were made at each station. In terrace edge and spur and grooves stations, SU was a $1 \mathrm{~m}^{2}$ frame (Weinberg 1981, Dodge et al. 1982) with 30 replicates

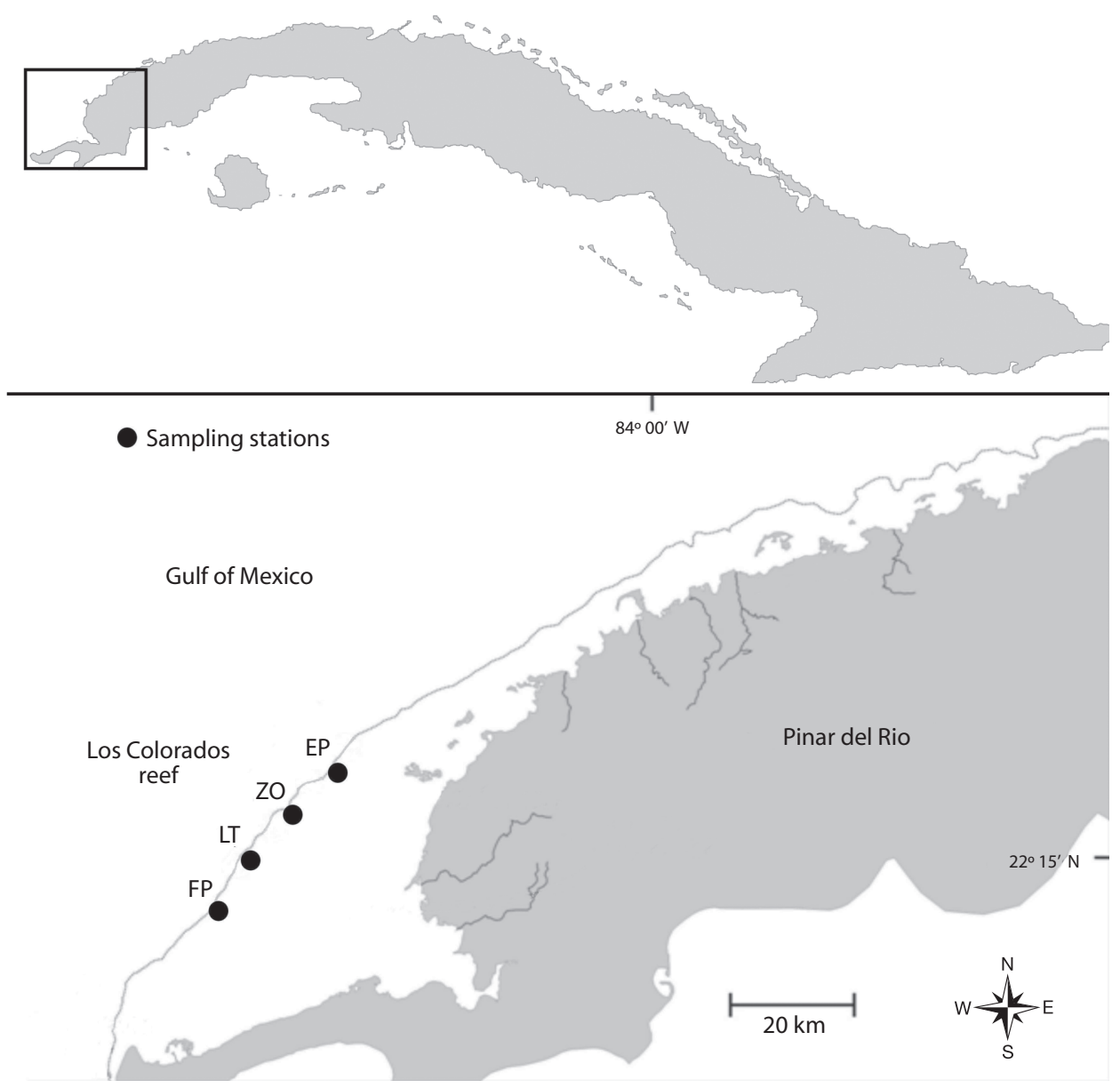

Fig. 1. Northwestern region of Cuban shelf. Circles indicate marine light platforms: Francisco Padre (FP), La Tabla (LT), Zorrita (ZO) and El Pinto (EP). 
by station. We followed the criteria of Zlatarski \& Martínez-Estalella (1980) for the identification of corals in situ. In our categorization of corals we include scleractineans corals, soft corals and hydrozoans (genus Millepora). The total number of gorgonian colonies and sponges were also recorded at each sampling unit in terrace edge and spur and grooves biotopes.

Data processing: Dissimilarity among sites and biotopes was assessed using several complementary methods. For a general comparative picture we used hierarchical agglomerative cluster analysis based on Bray-Curtis distances calculated with fourth-root transformed density values and group average (UPGMA) clustering algorithm. Significant differences among biotopes were determined using the ANOSIM routine with sampling sites as replicates inside each biotope. These analyses were performed using PRIMER 5 software (Clarke \& Warwick 2001). We also used abundance-based Sørensen estimators and their 95 percent confidence limits developed by Chao et al. $(2005,2006)$ to compare similarities among all pairs of sites inside each biotope. Calculations were made with EstimateS 8.0 software.

We computed expected species accumulation curves (sample-based rarefaction curves in the terminology of Gotelli \& Colwell 2001), with $95 \%$ confidence intervals, using the analytical formulas of Colwell et al. (2004) based in a Mao Tau estimator for number of species (S) included in EstimateS 8.0 software (Colwell 2006). For comparison of species richness $\mathrm{x}$-axis was re-scaled in units of individuals. The asymptotic tendency of the curves was taken as criteria to consider whether enough SUs were sampled. Shannon's index of total diversity $\left(H^{\prime}=\sum p_{i} \ln p_{i}\right.$, where $p i=$ proportion of species i) and Pielou's eveness index ( $\mathrm{J}^{\prime}=\mathrm{H}^{\prime} /$ $\ln$ S) were calculated with pooled data for each station. Variability of diversity indexes among stations inside each biotope was expressed as the ratio between highest and lowest values $(\mathrm{H} / \mathrm{L})$ and using the coefficient of variation $(\mathrm{CV}=\mathrm{SD} * 100 /$ mean, where SD is the standard deviation).
Densities (colonies $/ \mathrm{m}^{2}$ ) were calculated for each group of organisms (corals, sponges and gorgonians) in pooling all species and for selected coral species in each sampling station. The selection of species was based in the abundance and the percentage of representation of total number of colonies for coral species by each biotope. One way random effects analyses of variance (ANOVA) were performed was on fourth-root transformed data using STATISTICA 6.0 software.

\section{RESULTS}

A total of 2659 colonies of corals of 36 species were counted in 12 sites sampled (Table 1). Dominant species in crest biotope was Porites astreoides (Lamarck, 1816) with almost 50 percent of all counted colonies. This was followed by Millepora complanata (Lamarck, 1816) and Acropora palmata (Lamarck, 1816) which represented 25 percent of all the colonies. At terrace edge, a much more diverse assemblage was found. The most common species were Siderastrea siderea Ellis \& Solander, 1876, Stephanocoenia intersepta (Lamarck, 1816) and $P$. astreoides which accounted for more than 50 percent of the colonies. Montastraea cavernosa (Linnaeus, 1767) and Agaricia agaricites (Linnaeus, 1758), represent more than 9 percent of counted colonies in this biotope. In spur and grooves the results are similar to terrace edge. $S$. siderea, $S$. intersepta and $P$. astreoides were the most important ones representing almost 60 percent of all colonies while $M$. cavernosa and A. agaricites, accounts for only about 8 percent. These differences in the composition of coral assemblages among biotopes were significant (ANOSIM's Global $\mathrm{R}=0.956, \mathrm{p}=0.001$ )

After the numerical classification, stations were placed into two well separated groups (Fig. 2). Group A includes terrace edge and spur $\&$ groves stations while group $\mathrm{B}$, is comprised of the crest stations. Two subgroups are clearly distinguished inside group A. The first includes spur and grooves stations plus LT station from 
TABLE 1

Mean colony density (col/ $\mathrm{m}^{2} \pm$ standard error) and percentage representation of total number of colonies for coral species in each sampled biotope. Blank cell=absence

Species

Siderastrea siderea

Porites astreoides

Stephanocoenia intersepta

Millepora alcicornis

Porites porites

Montastraea faveolata

Montastraea cavernosa

Siderastrea radians

Agaricia agaricites

Meandrina meandrites

Madracis decactis

Dichocoenia stokesi

Manicina areolata

Eusmilia fastigiata

Helioseris cucullata

Montastraea franksi

Scolymia sp.

Mycetophyllia sp.

Favia fragum

Agaricia tenuifolia

Musa angulosa

Isophyllastrea sinuosa

Mycetophyllia aliciae

Colpophyllia natans

Diploria strigosa

Montastraea annularis

Acropora cervicornis

Agaricia lamarkiana

Agaricia humilis

Solenastrea sp.

Isophylastrea rigida

Diploria clivosa

Diploria labyrinthiformis

Millepora complanata

Palythoa caribaeorum

Madracis mirabilis

Acropora palmata

\begin{tabular}{cc}
\multicolumn{1}{c}{ Crest } \\
mean & $\%$ \\
$0.02 \pm 0.01$ & 0.7 \\
$0.99 \pm 0.23$ & 48.9 \\
& \\
&
\end{tabular}

$0.03 \pm 0.03$

$0.12 \pm 0.06$

1.6

6.1

48.9

Terrace ed
mean
$2.51 \pm 0.15$
$1.15 \pm 0.10$
$0.74 \pm 0.08$
$0.67 \pm 0.08$
$0.34 \pm 0.05$
$0.38 \pm 0.05$
$0.26 \pm 0.05$
$0.37 \pm 0.06$
$0.58 \pm 0.07$
$0.15 \pm 0.03$
$0.13 \pm 0.03$
$0.10 \pm 0.02$
$0.03 \pm 0.01$
$0.17 \pm 0.03$
$0.02 \pm 0.01$
$0.28 \pm 0.05$
$0.07 \pm 0.03$

$0.03 \pm 0.03$

1.5

$0.05 \pm 0.02$

$0.01 \pm 0.01$

$0.01 \pm 0.01$

$0.09 \pm 0.04$

$0.04 \pm 0.03$

$0.01 \pm 0.02$

4.5

$0.03 \pm 0.01$

$0.02 \pm 0.01$

$0.01 \pm 0.01$

$0.01 \pm 0.01$

$0.01 \pm 0.01$

$0.01 \pm 0.01$

$0.01 \pm 0.01$

$0.09 \pm 0.05$

$0.36 \pm 0.11$

$0.07 \pm 0.03$

$0.18 \pm 0.05$
4.7

$$
0.06 \pm 0.02
$$

$0.13 \pm 0.04$

$0.05 \pm 0.02$

$0.07 \pm 0.03$
Spur \& grooves mean \% $2.84 \pm 0.17 \quad 38.8$ $0.88 \pm 0.08 \quad 11.9$ $0.60 \pm 0.08 \quad 8.2$ $0.50 \pm 0.07 \quad 6.5$ $0.42 \pm 0.06 \quad 5.7$ $0.39 \pm 0.06 \quad 5.4$ $0.32 \pm 0.05 \quad 4.3$ $0.31 \pm 0.06 \quad 4.2$ $0.27 \pm 0.05 \quad 3.6$ $0.18 \pm 0.05 \quad 2.4$ $0.12 \pm 0.03 \quad 1.6$ $0.08 \pm 0.02 \quad 1.0$ $0.07 \pm 0.04 \quad 0.9$ $0.07 \pm 0.03 \quad 0.9$ $0.06 \pm 0.02 \quad 0.8$ $0.06 \pm 0.03 \quad 0.8$ $0.05 \pm 0.02 \quad 0.7$ $0.04 \pm 0.02 \quad 0.6$ $0.03 \pm 0.01 \quad 0.3$ $0.02 \pm 0.01 \quad 0.2$ $0.02 \pm 0.01 \quad 0.2$ $0.02 \pm 0.01 \quad 0.2$ $0.02 \pm 0.01 \quad 0.2$ $0.02 \pm 0.01 \quad 0.2$ $0.01 \pm 0.01 \quad 0.1$ $0.01 \pm 0.01 \quad 0.1$ terrace edge (A1) and the second is made up of the remaining terrace edge stations (A2).

Chao's estimates of Sorensen coefficients calculated among all possible pairs of sites inside each biotope (Fig. 3) yielded different variability patterns. Crest and spur and grooves showed relatively stable and high similarity mean values, while those in terrace edge were highly variable with a change of 15 percent between the lowest and highest values. 


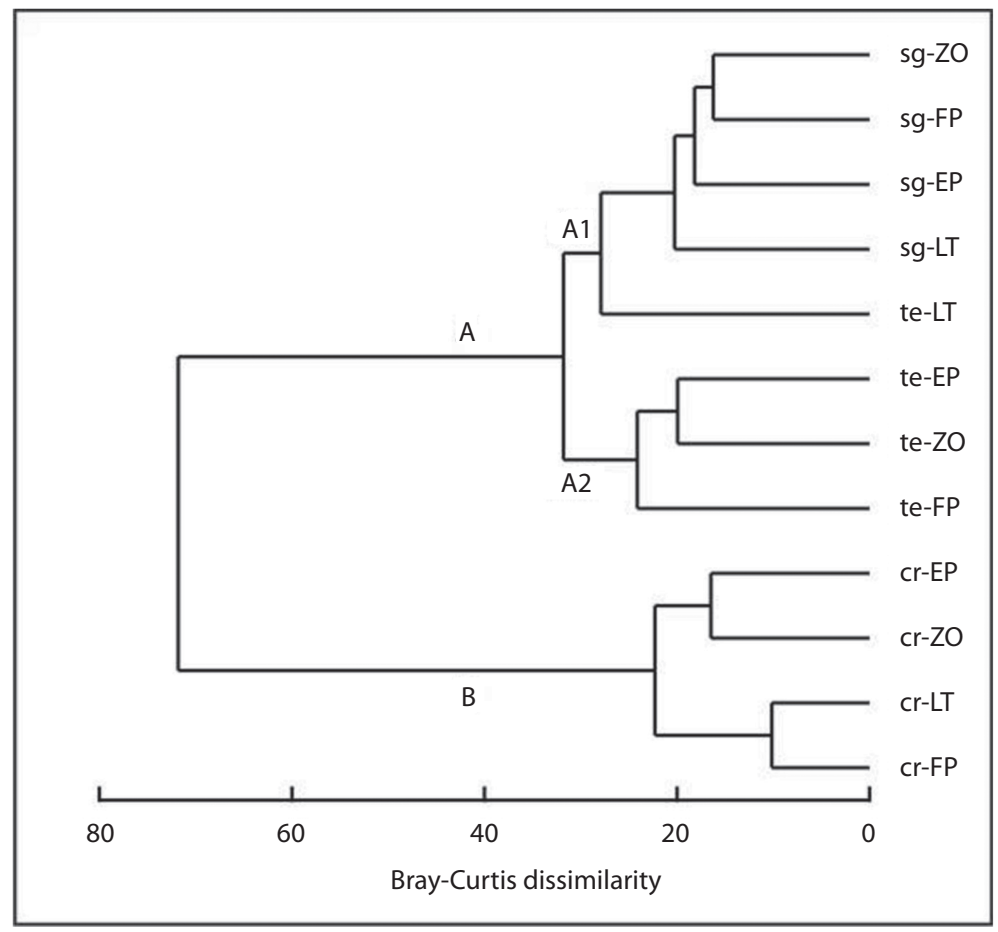

Fig. 2. Dendrogram showing results of numerical classification. Labels formed by biotope acronym (cr=crest, te $=$ terrace edge, $\mathrm{sg}=$ spur \& grooves) plus the sampling site acronym (see table 1). Upper case letters and numbers inside the graph identify groups described in text.

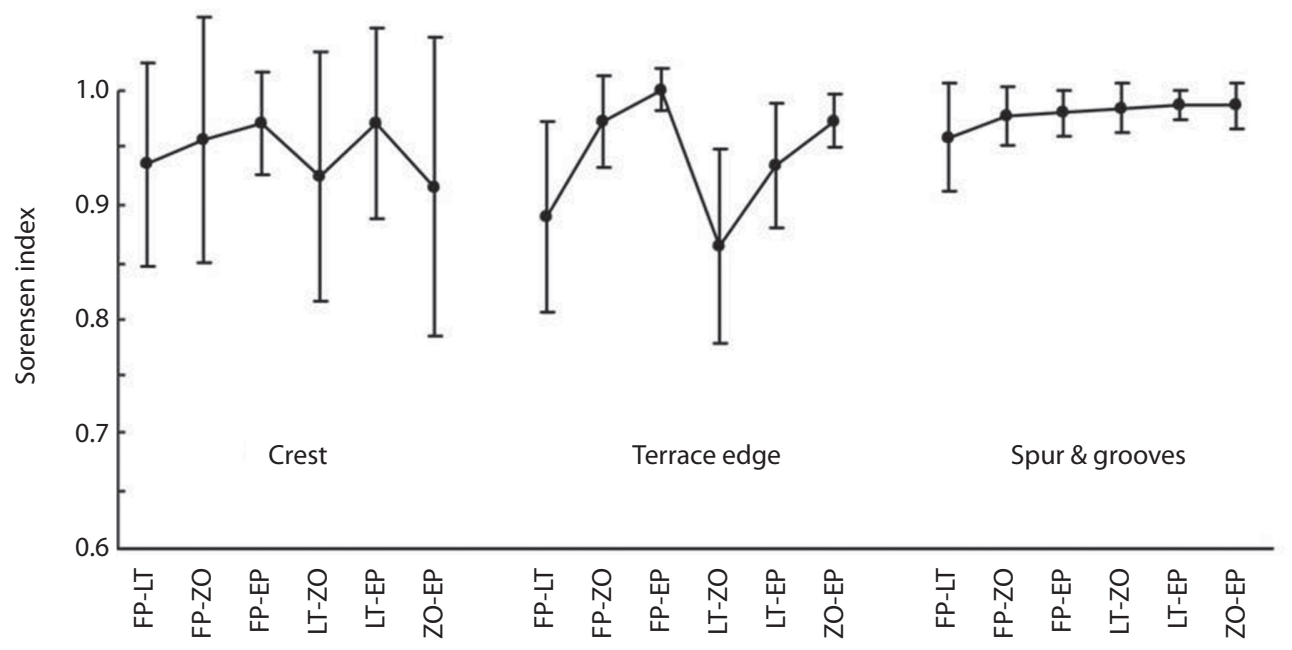

Fig. 3. Estimates of Sorensen indices ( \pm IC 95\%) for all pairs of sites at each biotope. 
Estimators in crest and terrace edge showed a much higher standard error than those in spur and grooves.

Diversity indexes were consistently lower among sites in crest stations compared to those in terrace edge and spur and grooves (Table 2), although J'value at the crest of EP was the highest observed for all samples. Variability for all indexes was higher among crest sites. $\mathrm{S}$ was always the most variable index inside each biotope but H' and J' yielded a more complex pattern. While in crest and spur and grooves relative change of H' was higher than that of J', the opposite was observed for terrace edge sites.

In general, expected species accumulation curves showed an asymptotic trend and a high overlap of estimated curves and confidence limits inside each biotope (Fig. 4). This means that after this approach, no statistical differences existed for most cases. The only exception was the pair LT-ZO inside crest biotope. It is clear that lower 95 percent confidence limit for LT expected values do no cover expected values for $\mathrm{ZO}$ and that upper limit of $\mathrm{ZO}$ do not cover the expected values of LT. Moreover, the 95 percent limits of these two sites do not overlap at all for highest individual cumulative numbers.

Variability of mean densities of selected coral species by sites showed different patterns for each biotope (Table 3). In crest sites, only $P$. astreoides yielded significant $\mathrm{F}$ values, with
TABLE 2

Coral's diversity indexes for each sampling station

\begin{tabular}{|c|c|c|c|c|c|c|}
\hline \multicolumn{7}{|c|}{ Crest } \\
\hline UM & 10 & 10 & 10 & 10 & - & - \\
\hline $\mathrm{N}$ & 239 & 191 & 242 & 136 & 1.76 & 24.7 \\
\hline S & 11 & 12 & 7 & 9 & 1.71 & 22.7 \\
\hline $\mathrm{H}^{\star}$ & 1.60 & 1.81 & 1.24 & 1.83 & 1.47 & 16.9 \\
\hline $\mathrm{J}^{\prime}$ & 0.67 & 0.73 & 0.64 & 0.83 & 1.29 & 11.7 \\
\hline \multicolumn{7}{|c|}{ Terrace edge } \\
\hline UM & 30 & 30 & 30 & 30 & - & - \\
\hline $\mathrm{N}$ & 182 & 249 & 213 & 328 & 1.80 & 23.0 \\
\hline S & 18 & 20 & 20 & 17 & 1.23 & 8.6 \\
\hline $\mathrm{H}^{\circ}$ & 2.33 & 2.34 & 2.34 & 2.30 & 1.10 & 4.1 \\
\hline $\mathrm{J}^{\prime}$ & 0.81 & 0.78 & 0.78 & 0.81 & 1.16 & 5.8 \\
\hline \multicolumn{7}{|c|}{ Spur \& grooves } \\
\hline UM & 30 & 30 & 30 & 30 & - & - \\
\hline $\mathrm{N}$ & 212 & 213 & 256 & 198 & 1.21 & 11.4 \\
\hline $\mathrm{S}$ & 18 & 18 & 25 & 18 & 1.38 & 17.7 \\
\hline $\mathrm{H}^{*}$ & 2.18 & 2.03 & 2.32 & 2.13 & 1.14 & 5.6 \\
\hline J' & 0.75 & 0.70 & 0.72 & 0.74 & 1.07 & 3.0 \\
\hline
\end{tabular}

UM: Number of sampling units; $\mathrm{N}$ : Total number of colonies; H': Shannon's diversity index; S: species richness; J': Pielou's eveness index; H/L: highest mean density value to lowest value ratio; $\mathrm{CV}$ : Coefficient of variation.

highest mean value (FP) four times higher than that of the lowest (EP). However, in terrace edge sites, mean densities of all analysed species were significantly different among sites. Three species showed highest values which were at least four times greater than the lowest
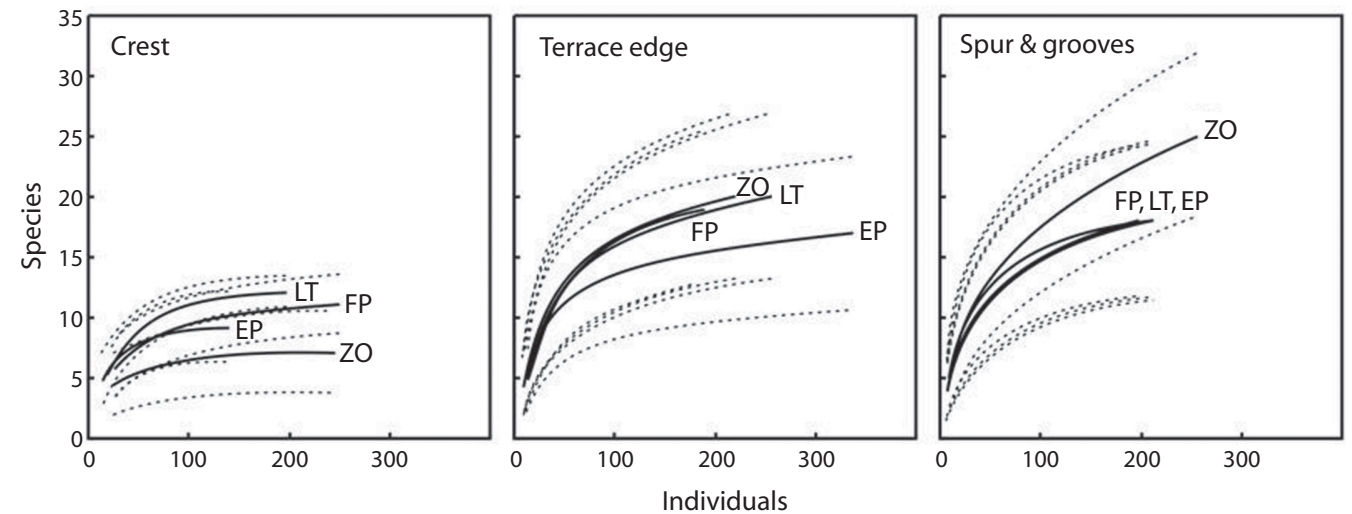

Fig. 4. Expected species accumulation curves (with 95\% confidence intervals) for sites in each biotope. 
TABLE 3

Mean density values ( \pm standard error) by sampling stations for selected coral species. Observed F-ratios and associated probabilities (p) for random effects ANOVAs are also showed. H/L: highest mean density value to lowest value ratio

\begin{tabular}{|c|c|c|c|c|c|c|c|}
\hline Species & FP & LT & $\mathrm{ZO}$ & EP & $\mathrm{F}$ & $\mathrm{p}$ & $\mathrm{H} / \mathrm{L}$ \\
\hline \multicolumn{8}{|l|}{ Crest } \\
\hline Millepora complanata & $4.4 \pm 0.9$ & $2.0 \pm 0.7$ & $4.1 \pm 1.1$ & $3.8 \pm 0.8$ & 1.31 & 0.280 & 2.20 \\
\hline Acropora palmata & $1.7 \pm 0.5$ & $1.7 \pm 0.6$ & $2.0 \pm 0.4$ & $1.6 \pm 0.4$ & 0.12 & 0.950 & 1.25 \\
\hline Porites astreoides & $11.8 \pm 1.5$ & $9.4 \pm 1.7$ & $14.7 \pm 2.3$ & $3.6 \pm 0.5$ & 2.42 & $<0.001$ & 4.08 \\
\hline \multicolumn{8}{|l|}{ Terrace edge } \\
\hline Siderastrea siderea & $1.6 \pm 0.3$ & $2.4 \pm 0.3$ & $1.8 \pm 0.2$ & $2.5 \pm 0.3$ & 9.78 & $<0.001$ & 2.50 \\
\hline Stephanocoenia intersepta & $0.5 \pm 0.1$ & $0.8 \pm 0.2$ & $0.4 \pm 0.1$ & $0.5 \pm 0.1$ & 3.11 & 0.020 & 3.75 \\
\hline Porites astreoides & $0.9 \pm 0.1$ & $1.5 \pm 0.3$ & $1.2 \pm 0.2$ & $1.7 \pm 0.3$ & 5.30 & $<0.001$ & 4.25 \\
\hline Agaricia agaricites & $0.2 \pm 0.1$ & $0.3 \pm 0.1$ & $0.9 \pm 0.2$ & $1.0 \pm 0.2$ & 4.73 & $<0.001$ & 5.00 \\
\hline Montastraea cavernosa & $0.1 \pm 0.1$ & $0.2 \pm 0.1$ & $0.2 \pm 0.1$ & $0.9 \pm 0.2$ & 6.70 & $<0.001$ & 9.00 \\
\hline \multicolumn{8}{|l|}{ Spur \& grooves } \\
\hline Siderastrea siderea & $2.8 \pm 0.3$ & $3.1 \pm 0.3$ & $3.1 \pm 0.4$ & $2.4 \pm 0.3$ & 0.88 & 0.500 & 1.29 \\
\hline Stephanocoenia intersepta & $0.6 \pm 0.1$ & $0.8 \pm 0.2$ & $0.8 \pm 0.2$ & $0.3 \pm 0.1$ & 3.02 & 0.030 & 2.67 \\
\hline Porites astreoides & $0.8 \pm 0.2$ & $0.9 \pm 0.1$ & $0.9 \pm 0.1$ & $0.9 \pm 0.2$ & 0.11 & 0.950 & 1.13 \\
\hline Agaricia agaricites & $0.4 \pm 0.1$ & $0.2 \pm 0.1$ & $0.3 \pm 0.1$ & $0.1 \pm 0.1$ & 1.41 & 0.240 & 4.00 \\
\hline Montastraea cavernosa & $0.2 \pm 0.1$ & $0.3 \pm 0.1$ & $0.4 \pm 0.1$ & $0.4 \pm 0.1$ & 0.66 & 0.600 & 2.00 \\
\hline
\end{tabular}

Degrees of freedom for F tests: Crest=3,36; Terrace edge=3,116; Spur and grooves=3,116.

one. Low variability was also found in spur $\&$ groove sites. Only $S$. intersepta yielded a significant $\mathrm{F}$ value with highest values (LT, ZO) almost three times higher than the lowest one (EP).

Mean densities of major groups of sessile invertebrates also showed different variability patterns among sites with respect to each biotope (Table 4). Coral densities were significantly different among sites in crest and terrace edge, with highest values almost two times higher than lowest values. Spur and grooves sites were homogeneous for this group. Sponges showed significant difference just in terrace edge where the highest value of mean density was twice the lowest one. Gorgonians yielded

TABLE 4

Mean density values ( \pm standard error) by sampling stations for major sessile groups. Observed F-ratios and associated probabilities ( $p$ ) for random effects ANOVAs are also showed. H/L: highest mean density value to lowest value ratio

\begin{tabular}{|c|c|c|c|c|c|c|c|}
\hline Sessile groups & FP & LT & $\mathrm{ZO}$ & EP & $\mathrm{F}$ & $\mathrm{p}$ & $\mathrm{H} / \mathrm{L}$ \\
\hline \multicolumn{8}{|l|}{ Crest } \\
\hline Corals & $23.9 \pm 1.8$ & $24.2 \pm 1.5$ & $19.1 \pm 1.8$ & $13.6 \pm 1.3$ & 9.71 & $<0.001$ & 1.78 \\
\hline \multicolumn{8}{|l|}{ Terrace edge } \\
\hline Corals & $6.1 \pm 0.4$ & $7.1 \pm 0.5$ & $8.3 \pm 0.8$ & $10.9 \pm 0.9$ & 8.71 & $<0.001$ & 1.78 \\
\hline Sponges & $2.8 \pm 0.2$ & $3.9 \pm 0.3$ & $4.5 \pm 0.6$ & $5.6 \pm 0.4$ & 8.06 & $<0.001$ & 2.00 \\
\hline Gorgonians & $5.6 \pm 0.5$ & $6.5 \pm 0.5$ & $8.1 \pm 1.2$ & $6.3 \pm 0.4$ & 14.6 & $<0.001$ & 1.44 \\
\hline \multicolumn{8}{|l|}{ Spur \& grooves } \\
\hline Corals & $6.1 \pm 0.4$ & $7.2 \pm 0.6$ & $6.1 \pm 0.3$ & $5.7 \pm 0.4$ & 2.20 & 0.092 & 1.26 \\
\hline Sponges & $4.2 \pm 0.3$ & $3.7 \pm 0.3$ & $3.3 \pm 0.3$ & $3.5 \pm 0.4$ & 1.44 & 0.235 & 1.27 \\
\hline Gorgonians & $2.5 \pm 0.3$ & $3.3 \pm 0.5$ & $8.2 \pm 0.7$ & $4.4 \pm 0.6$ & 18.8 & $<0.001$ & 3.28 \\
\hline
\end{tabular}

Degrees of freedom for F tests: Crest=3,36; Terrace edge=3,116; Spur and grooves=3,116. 
significant $F$ values for both terrace edge and spur and grooves biotopes with maximum of variability among sites in spur and grooves; here the highest value was more than three times greater than the lowest one.

\section{DISCUSSION}

We found differences among sites for several indicators. The variation observed can be considered as natural in origin. In other words, sites inside a well preserved reef unit present notable natural differences and variability in the composition of their communities. This result reinforces the need claimed by other authors (Underwood 1992, Underwood \& Chapman 2003, Terlizzi et al. 2005) of using several control or reference sites to avoid spatial statistical confounding in any study focused on human impact assessment.

The nature and magnitude of observed differences varied independently among biotopes, ecological indicators, species and groups of species. In general terms, spur and grooves biotope showed less variability while terrace edge was the most variable when considering all of the indicators. Huston (1985) found a diversity pattern in reefs near Eilat in the Red Sea similar to those obtained in our research. However, no clear trends could be found among indicators, species and groups of species. It is highly probable that the observed differences in this research would change in nature and magnitude when other well preserved reefs are investigated in the same way (Pandolfi 2002). Therefore, the main point to be made is that multiple sites must be sampled in any reef in order to obtain a more realistic panorama of the state of the communities under study. This is an important methodological premise if we want to detect human impacts through comparison of reefs under different levels of anthropogenic stress.

Research done in Cuban waters at a scale of $10-15 \mathrm{~km}$ has determined some reefs which are not far from cities as reference sites (GonzálezDíaz 1999, Guardia \& González-Sansón 2000 b, González-Ferrer 2000, Caballero 2002,
Alvarez, 2006). Values of diversity indexes obtained in those studies are equal or smaller than those found in our research. Comparisons among biotopes show highest values in terrace edge. Other research efforts (Guardia \& González-Sansón 2000b, Guardia et al. 2001, González-Díaz et al. 2003) have focused on the effects of well defined contaminant sources (e.g. Havana harbour, Almendares River) on inshore marine invertebrate's communities. Compared to values found in our research, these studies yielded smaller values for diversity indices in impacted sites but similar values in reference sites.

Castellanos et al. (2004) found coral density values for healthy crests lower $\left(6,5 \mathrm{col} / \mathrm{m}^{2}\right)$ than values found in our research. In another reef near to Havana, that is impacted by river discharges rich in organic compounds and is under the impact of a tourist centre, Caballero \& Guardia (2003) found a much lower coral density $\left(2,6 \mathrm{col} / \mathrm{m}^{2}\right)$.

González-Ferrer (2000) investigated terrace edge biotopes in two healthy reefs near Havana and found coral and sponge density values similar to those found in our research. Guardia \& González-Sanson (2000b) sampled terrace edge coral communities in a highly polluted reef adjacent to the Havana harbour entrance. They found values of coral and gorgonians density lower than those found in our research. In contrast, sponge density in their study was higher. Sponge density values found by Guardia \& Gonzalez-Sansón (2000b) may be reflecting high organic pollution coming from Havana harbor. Organic pollution in moderate quantities may benefit sponges by providing nutrients for heterotrophic bacteria which are a food source for sponges which feed by filtration, targeting mainly ultraplankton (Rützler 2004). A positive relationship of sponge biomass with organic pollution and high sediment load has been accepted by several authors (Chalker et al. 1985, Rogers 1990, Wilkinson \& Cheshire 1990, Ward-Paige et al. 2005, Costa et al. 2008). Concerning nutrient and sediment increases, sponges and corals can be considered as opposites, with coral biomass decreasing in 
reefs stressed by pollution and siltation (Aerst \& van Soest 1997, Nughes \& Roberts 2003a). Sponge cover was negatively correlated with hard coral cover in the Florida Keys (Maliao et al. 2008). These results also support the lower coral and gorgonian density found by Guardia \& Gonzalez-Sanson (2000b).

Guardia et al. (2001) investigated spur and grooves in reefs adjacent to the mouth of the Almendares River (medium impacted zone). Compared to our own results these authors found lesser values for coral and gorgonian densities and higher values for sponges densities. From a site off Havana city with a low impact level, Alvarez (2006) reports values in spur and grooves similar to ours for corals $\left(6,6 \mathrm{col} / \mathrm{m}^{2}\right)$, however higher for sponges $\left(7,8 \mathrm{col} / \mathrm{m}^{2}\right)$ and gorgonians $\left(6.8 \mathrm{col} / \mathrm{m}^{2}\right)$.

Based on our results, we suggest including M. complanata, A. palmata and $P$. astreoides in research of species population levels in crest biotopes from these reefs. These species are recognised as typical of this biotope and are very resistant to wave action (Sorokin 1993, Lewis 1997). Bellwood et al (2004) suggest that A. palmata is a critical functional group which is missing in most of the Caribbean region and remains dominant only in healthy reefs. In other Cuban reefs near the coast (Baracoa and Rincon de Guanabo reefs) A. palmata has similar density as that found in our research, but $P$. astreoides has higher densities in Baracoa (Gonzalez-Díaz et al. 2008, Perera 2008).

Future research in terrace edge and spur and groove biotopes in our study area should include $S$. siderea, $S$. intersepta, $P$. astreoides, A. agaricites and $M$. cavernosa. It is important to emphasise that terrace edge biotope exhibits the highest variability of density for these species among sites. We also suggest that it will be useful to analyze density variability in other relatively homogeneous and non-impacted terrace edges with special focus on the variability of $M$. cavernosa. All these species (except $A$. agaricites) were identified as having colony structure with capacity to resist high turbulence and sedimentation (Martínez-Estallela \& Herrera 1989, Meesters et. al. 1992).
Steiner (1999) found (coinciding with our research) that $S$. siderea and $P$. astreoides were bathymetric generalists (can live in a broad depth range). Nevertheless, $P$. astreoides was more abundant in shallower and more turbulent waters with less apparent spatial competition. However, S. siderea, by contrast, abounded mostly in deeper and denser coral assemblages. De la Guardia and González-Sanson (2000b), De la Guardia et al. (2001) and González-Díaz et al. (2003) also report these species, along with $S$. radians and $M$. cavernosa, as resistant species to environmental stress.

With respect to the abundance of $A$. agaricites, our results are similar to other research findings. In reefs located far from significant anthropogenic disturbances, Guardia and González-Sanson (1997b), Caballero et al. (2004) and Guardia et al. (2006) found A. agaricites was the most abundant species. Similar results were obtained by González-Díaz et al. (2003) and Caballero \& Guardia (2003) in reefs under low human impact off Havana and considered these as strong reference sites for a local scale study. Sullivan et al. (2004) and Beltran-Torres et al. (2003) found that A. agaricites is vulnerable to sedimentation and appear in high densities in healthy reefs.

An unexpected result in our research was the high density of the coral species, $S$. intersepta. We found this species as one of the more abundant (with 4,6 to $15,9 \%$ of relative abundance) in our samples. Other research carried out in Cuban waters on healthy and unhealthy reefs do not report this species among those accounting for $95 \%$ of all identified colonies (Guardia \& González-Sanson 1997a, González 1999, González-Ferrer 2000, Guardia \& González-Sanson 2000b, Caballero 2002, Álvarez 2006). Several authors report this species in their studies but always in a very low percent of numerical representation (González-Díaz et al. 2003, Caballero \& de la Guardia 2003, Caballero et al. 2004 and Guardia et al. 2006 in Cuba, Beltran-Torres et al. 2003 in Mexico and Sullivan 2004 in Central Bahamas). On the other hand, Steiner (1999) measured relative abundance values 
for this species between 5,5 to $11,4 \%$ in South Caicos in southeastern Bahamian archipelago. Schmahl et al. (2004) report deep coral assemblages at McGrail Bank (39-44 meters) which are composed primarily of the blushing star coral (S. intersepta) at densities approaching $30 \%$ of benthic surface cover.

In summary, we found that several ecological indicators showed differences between sites and biotopes. Nevertheless, no evidence exists to associate these differences to human impact. We hypothesize that differences in these invertebrates' communities are the consequence of inherent ecological processes typical of reefs ecosystems (biotic interactions as predation and competition acting together responding to natural abiotic gradients of depth, light, turbulence and wave effect). Integrated analysis of ecological indicators show that environmental conditions in Los Colorados are better than in "reference sites" defined for local studies off Havana and can be compared with healthy reefs of other sites of Cuba and the Caribbean region. In a broad spatial context we suggest using Los Colorados as reference reefs in studies aiming to detect human impact. Also, the high abundance of $S$. intersepta found in our research deserves a closer examination in future research. We also recommend continuing this research to evaluate ecological indicators at the population level with a special focus in population structure, diseases and bleaching.

\section{ACKNOWLEDGMENTS}

We thank the Bay and Paul Foundations who funded this research as well as the Harte Research Institute for Gulf of Mexico Studies who support a project to study the NW Cuban shelf. Special thanks to D. Guggenheim and F. Bretos for their support and friendship. We are very grateful for field assistance provided primarily by two divers who are also excellent people: Ivan Rodriguez Mauri and Eduardo Alonso from the Center for Marine Research of the University of Havana. We appreciate the time and efforts of Alberto Salazar and Fernando Bretos for assisting in providing the
English translation of this manuscript. We are equally grateful for the critical opinions of the referees.

\section{RESUMEN}

El objetivo principal de la investigación fue obtener una línea base de la composición de las comunidades de esponjas, corales y gorgonias que pueda ser utilizada como referencia para futuros análisis de impacto antrópico. Nuestra hipótesis es que un arrecife relativamente homogéneo y bien conservado, presenta una variabilidad natural notable en la composición de sus comunidades, lo cual no está asociado con cambios en la proximidad a tierra o a un gradiente de impacto humano. La investigación se llevó a cabo en julio de 2006, en 12 estaciones de muestreo ubicadas en el arrecife de Los Colorados, en la región noroccidental de la Provincia de Pinar del Río, Cuba. Los biotopos seleccionados fueron cresta, veril y camellones. Los indicadores ecológicos estimados fueron: diversidad de corales, composición por especies, densidad de corales, hidrocorales, gorgonias y esponjas, y densidad de especies de corales seleccionadas. Se contaron 2659 colonias de corales escleractíneos pertenecientes a 36 especies. Las especies más abundantes en el biotopo de cresta fueron: Millepora alcicornis, Acropora palmata y Porites astreoides; mientras que en el veril y los camellones fueron Siderastrea siderea, Stephanocoenia intersepta, Porites astreoides, Agaricia agaricites y Montastraea cavernosa. Entre sitios, se encontraron diferencias significativas estadísticamente para varios indicadores (densidad de corales, esponjas y gorgonias y densidad de especies seleccionadas), pero ello no pudo asociarse con ningún gradiente de uso de la tierra o de impacto humano. Por lo tanto, sitios dentro de un arrecife relativamente homogéneo pueden presentar diferencias notables en la composición de sus comunidades.

Palabras clave: variabilidad natural, indicadores ecológicos, comunidades de invertebrados bentónicos, biotopos, Cuba.

\section{REFERENCES}

Adams, S.M. 2005. Assesing cause and effect of multiple stressors on marine systems. Mar. Poll. Bull. 51: 649-657.

Aerst, L.A.M. \& R.W.M. Van Soest. 1997. Quantification of sponge/coral interactions in a physically stressed reef community, NE Colombia. Mar. Ecol. Prog. Ser. 148: $125-134$.

Álvarez, S.F. 2006. Estimación de indicadores ecológicos a nivel de comunidad y población de corales 
hermatípicos en un sitio de referencia del litoral habanero. Tesis de diploma, Centro de Investigaciones Marinas, Universidad de La Habana, La Habana, Cuba.

Bak, R.P.M. \& E.H. Meesters. 1998. Coral population structure: the hidden information of colony sizefrequency distributions. Mar. Ecol. Prog. Ser. 162: 301-306.

Bellwood, D.R., T.P. Hughes, C. Folke \& M. Nystrom. 2004. Confronting the coral reef crisis. Nature 429: $827-833$

Beltran-Torres, A., L. Muñoz-Sánchez \& J.P. CarricartGanivet. 2003. Effects of hurricane Keith at a patch reef on Banco Chinchorro, Mexican Caribbean. Bull. Mar. Sci. 73: 187-196.

Caballero, H.A. 2002. Estructura de la comunidad coralina de tres sitios de la costa norte de La Habana, Cuba. Tesis de Maestría en Biología Marina y Acuicultura, Centro de Investigaciones Marinas, Universidad de La Habana, La Habana, Cuba.

Caballero, H. \& E. de la Guardia. 2003. Arrecifes de coral utilizados como zonas de colectas para exhibiciones en el Acuario Nacional de Cuba. I. Costa Norooccidental de La Habana, Cuba. Rev. Invest. Mar. 24: 205-220.

Caballero, H., G. Varona \& Y. García. 2004. Estructura ecológica de las comunidades de corales de la costa oriental de Bahía de Cochinos, Cuba. Rev. Invest. Mar. 25: 23-36.

Castellanos, S., A. Lopeztegui \& E. de la Guardia. 2004. Monitoreo Reef Check en el arrecife coralino "Rincón de Guanabo", Cuba. Rev. Invest. Mar. 25: 219-230.

Chalker, B.E., K. Carr \& E. Gill. 1985. Measurement of primary production and calcification in situ on coral reefs using electrode techniques. Proc. 5th Int. Coral Reefs Cong., Tahiti 6: 167-172.

Chao, A., R.L. Chazdon, R.K. Colwell \& T. Shen. 2005. A new statistical approach for assessing similarity of species composition with incidente and abundante data. Ecology Letters 8: 148-159.

Chao, A., R.L. Chazdon, R.K. Colwell \& T. Shen. 2006. Abundance-Based similarity indices and their estimation when there are unseen species in samples. Biometrics 62: 271-371.

Clarke, K.R. \& R.M. Warwick. 2001. Change in marine communities: An approach to statistical Analysis and
Interpretation. Primer-E Plymouth Marine Laboratory, Plymouth, United Kingdom.

Colwell, R.K., C.X. Mao \& J. Chang. 2004. Interpolating, extrapolating, and comparing incidente-based species accumulation curves. Ecology 85: 2717-2727.

Colwell, R.K. 2006. EstimateS: Statistical estimation of species richness and shared species from samples. Version 8. Persistent URL: purl.oclc.org/estimates.

Connell, J.H., T.P. Hughes \& C.C. Walace. 1997. A 30 year study of coral abundance, recruitment, and disturbance at several scales in space and time. Ecol. Monogr. 67: 461-488.

Costa Jr. O.S., M. Nimmo \& M.J. Attrill. 2008. Coastal nitrification in Brazil: A review of the role of nutrient excess on coral reef demise. J. S. Am. Earth Sci. 25: 257-270.

Dale, H.V. \& S.C. Beyeler. 2001. Challenges in the development and use of ecological indicators. Ecol. indicators $1: 3-10$.

Dodge, R.E., A. Logan \& A. Antonius. 1982. Quantitative reef assessment studies in Bermuda: A Comparison of Methods and Preliminary Results. Bull. Mar. Sci. 32: 745-760.

English, C., V. Wilkinson \& V. Baker. 1997. ASEANAustralia Marine Science Project: Living Coastal Resources, Townsville, Australia.

Fabricius, K.E., G. De'ath, L. McCook, E. Turak \& D. McB Williams. 2004. Changes in algal, coral and fish assemblages along water quality gradients on the inshore Great Barrier Reef. Mar. Poll. Bull. 48: 101-111.

González-Díaz, P. 1999. Comunidades de esponjas, corales y gorgonias en un arrecife coralino costero de Ciudad de la Habana, Tesis de diploma, Universidad de la Habana, La Habana, Cuba.

González-Díaz, S., E. de la Guardia \& G. GonzálezSansón. 2003. Efecto de efluentes terrestres sobre las comunidades bentónicas de arrecifes coralinos de Ciudad de La Habana, Cuba. Rev. Invest. Mar. 24: 193-204.

González-Díaz, S.P., G. González-Sansón, Y. Piloto Cubero, Y. Cabrales \& S. Álvarez Fernández. 2008. Estructura de las poblaciones de Acropora palmata, Porites astreoides y Agaricia agaricites forma masiva (Cnidaria; Scleractinia) en el arrecife de Playa Baracoa, Cuba. Rev. Invest. Mar. 29: 213-223. 
González-Ferrer, S. 2000. Caracterización de tres comunidades de corales del litoral norte de La Habana y Ciudad de La Habana. Tesis de diploma, Universidad de la Habana, La Habana, Cuba.

González-Sansón, G., C. Aguilar, I. Hernández, Y. Cabrera $\&$ A. Curry. 2009. The influence of habitat and fishing on reef fish assemblages in Cuba. Gulf and Caribbean Research 21: 13-21.

Gotelli, N. \& R. Colwell. 2001. Quantifying biodiversity: procedures and pitfalls in the measurement and comparision of species richness. Ecology Letters 4: 379-391.

Guardia, E. \& G. González-Sansón. 1997 a. Asociaciones de esponjas, gorgonias y corales en un arrecife en la costa noroccidental de Cuba. II: Variaciones espaciales del cubrimiento y la densidad. Rev. Invest. Mar. 18: 208-215.

Guardia, E. \& G. González-Sansón. 1997 b. Asociaciones de esponjas, gorgonias y corales en un arrecife en la costa noroccidental de Cuba. III: Variación espacial de la diversidad. Rev. Invest. Mar. 18: 216-222.

Guardia, E. \& G. González-Sansón. 2000b. Asociaciones de corales, gorgonias y esponjas del sublitoral habanero al Oeste de la bahía de La Habana. II Índices ecológicos. Rev. Invest. Mar. 21: 9-16.

Guardia, E., P. González-Díaz \& J. Trelles. 2001. Macrobentos del arrecife coralino adyacente al Río Almendares, Cuba. Rev. Invest. Mar. 22: 167-178.

Guardia, E, P. González-Díaz \& G. González-Sansón. 2006. Descripción de puntos de buceo en Cayo Levisa, Archipiélago de Los Colorados, Cuba. Rev. Invest. Mar. 27: 133-146.

Hill, J. \& C. Wilkinson. 2004. Methods for Ecological Monitoring of Coral Reefs. A Resource for Managers. Australia Institute of Marine science and Reef Check, Townsville, Australia.

Hughes, T.P., A.H. Baird, D.R. Bellwood, M. Card, S.R. Connolly, C. Folkes, R. Grosberg, O. Hoegh-Guldberg, J.B.C. Jackson, J. Kleypas, J.M. Lough, P. Marshal, M. Nystrom, S.R. Palumi, J.M. Pandolfi, B. Rosen \& J. Roughgarden. 2003. Climate Change, Human Impacts and the Resilience of Coral Reefs. Science 31: 929-933.

Hughes, A.R., J.E. Byrnes, D.L. Kimbro \& J.J. Stachowicz. 2007. Reciprocal relationships and potential feedbacks between biodiversity and disturbance. Ecology Letters 10: 849-864.
Huston, M.A. 1985. Patterns of species diversity on coral reefs. Ann. Rev. Ecol. Syst. 16: 149-177.

Karlson, R.H \& H.V. Cornell. 1998. Scale-dependent variation in local vs regional effects on coral species richness. Ecol. Monograph 68: 259-274.

Lewis, J.B. 1997. Abundance, distribution and partial mortality of the massive coral Siderastrea siderea on degrading coral reefs at Barbados, West Indies. Mar. Poll. Bull. 34: 622-627.

Maliao, R.J., R.G. Turingan \& J. Lin. 2008. Phase-shift in coral reef communities in the Florida Keys National Marine Sanctuary (FKNMS), USA. Mar. Biol. 154: 841-853.

Martínez-Estallela, N. \& A. Hererra. 1989. Estudio de la comunidad coralina del Rincón de Guanabo, Cuba. Academia de Ciencias de Cuba, Instituto de Oceanología, Reporte de Investigaciones 9: 28.

Meesters, H.E., A. Bos \& G.J. Gast. 1992. Effects of sedimentation and lesion position on coral tissue regeneration. Proc. Sev. Inter. Coral Reef Symp., Guam. 2: 671-678.

Munkittrick, K.R. \& L.S. McCarty. 1995. An integrated approach to aquatic ecosystem health: top down, bottom-up or middle-out? J. Aquatic Ecos. Health 4: 77-90.

Nughes, M.M. \& C.M. Roberts. 2003a. Partial mortality in massive reef corals as an indicator of sediment stress on coral reefs. Mar. Poll. Bull. 46: 314-323.

Nughes, M.M. \& C.M. Roberts. 2003. Coral mortality and interaction with algae in relation to sedimentation. Coral reefs 22: 507-516.

Oficina Nacional de Estadística. 2005. Censo población y vivienda 2002. Informe Nacional.

Pandolfi, J.M. 2002. Coral community dynamics at multiple scales. Coral reefs 21: 13-23.

Pandolfi, J.M. 2003. Global trajectories of the long-term decline of coral reef ecosystems. Science 301: 955 958.

Perera, O. 2008. Estimación de indicadores ecológicos en dos poblaciones de Acropora palmata (Cnidaria: Scleractinia) del litoral norte de las provincias Habaneras. Tesis de diploma, Universidad de la Habana, La Habana, Cuba.

Rogers, C.S. 1990. Responses of coral reefs and organisms to sedimentation. Mar. Ecol. Prog. Ser. 62: 185-202. 
Rogers, C.S., G. Garrison, R. Grober, Z.M. Hillis \& M.A. Franke. 2001. Coral reef monitoring manual for the Caribbean and Western Atlantic. 340: 693-8950.

Rützler, K. 2004. Sponges on coral reefs: a community shaped by competitive cooperation. Boll. Mus. Ist. Biol. Univ. Genova 68: 85-148.

Schmahl, G.P., E.L. Hickerson \& D.C. Weaver. 2004. Technological Approaches to the Assessment of Deepwater Coral Reefs in the Northwestern Gulf of Mexico. 10th International Coral Reefs Symposium (Abstracts).

Sorokin, Y.I. 1993. Coral reef ecology. Springer, Berlin, Germany.

Steiner, S.C.C. 1999. Species presence and distribution of Scleractinia (Cnidaria:Anthozoa) from South Caicos, Turks and Caicos Island. Bull. Mar. Sci. 65: 861871.

Sealey, K.S. 2004. Large-scale ecological impacts of development on tropical islands systems: comparison of developed and undeveloped islands in the Central Bahamas. Bull. Mar. Sci. 75: 295-320.

Terlizzi, A., L. Benedetti-Cecchi, S. Bevilacqua, S. Fraschetti, P. Guidetti \& M.J. Anderson. 2005. Multivariate and univariate asymmetrical analyses in environmental impact assessment: a case study of Mediterranean subtidal sessile assemblages. Mar. Ecol. Prog. Ser. 289: 27-42.

Underwood, A.J. 1992. Beyond BACI: the detection of environmental impacts on populations in the real, but variable, world. J. Exp. Mar. Biol. Ecol. 161: 145-178.

Underwood, A.J. \& M.G. Chapman. 2003. Power, precaution, Type II error and sampling desing in assessment of environmental impacts. J. Exp. Mar. Biol. Ecol. 296: 49-70.

Ward-Paige, C.A., M.J. Risk, O.A. Sherwood \& W.C. Jaap. 2005. Clionid sponge surveys on the Florida reef tract suggest land-based nutrient inputs. Mar. Pollut. Bull. 51: $570-579$.

Weinberg, S. 1981. A Comparison of Coral Reef Survey Methods. Bijdragen tot de Dierkunde 51: 199-218.

Wilkinson, C.R. 2002. Executive Summary. Status of coral reefs of the world: 2000. Global Coral Reef Monitoring Network and Australian Institute of Marine Science, Townsville, Australia.

Wilkinson, C.R. \& A.C. Cheshire. 1990. Comparisons of sponge populations across the Barrier Reefs of Australia and Belize evidence for higher productivity in the Caribbean Mar. Ecol. Prog. Ser. 67: 285-294.

Zlatarski, V. \& N. Martínez-Estalella. 1980. Los escleractinios de Cuba y datos de los organismos acompañantes (en Ruso). Edit. Academia de Ciencias de Bulgaria, Sofia, Bulgaria.

\section{REFERENCIA DE INTERNET}

AFP. 2009. Expectativa en Cuba ante nueva perforación petrolera en Golfo de México. (Consultado 12 abril 2009, http://www.CUPET com.।Pdvsa y Cupet realizarán exploraciones en Golfo de México.htm). 